\title{
Türkçe Kısa Mesajları Sınıflandıran Çok Katmanlı Süzgeçleme Mimarisi ve Akıllı SMS Kutusu
}

\author{
A Novel Multi-tier Filtering Architecture and Smart SMS Box for Classification of Turkish Short \\ Messages
}

\author{
Halil İbrahim BESTIL ${ }^{1}$ (D) M. Amaç GÜVENSAN1 ${ }^{10}$ \\ ${ }^{I} Y$ lldız Teknik Üniversitesi, Elektrik-Elektronik Fakültesi, Bilgisayar Mühendisliği Bölümü, 34220, Esenler / İstanbul
}

$\ddot{\mathbf{O z}}$

Kısa mesaj servisi en yaygın kullanılan iletişim kanallarından biridir. Kişisel, reklam, promosyon, etkinlik bildirimi, satış onaylama vb. birçok farklı amaç için kullanılan kısa mesajların sayısının her geçen gün artması takip edilebilirliklerini ve aranan mesajın mesaj kutusunda hızlıca bulunmasını zorlaştırmaktadır. Öte yandan istenmeyen mesajların mesaj kutusunu doldurması ve mesaj kirliliği yaratması bir diğer önemli problemdir. Bu çalışmada Türkçe Kısa Mesajları sınıflandırmak ve akıllı bir SMS kutusu oluşturmak amacıyla Çok Katmanlı Süzgeçleme Mimarisi önerilmiştir. Ayrıca bu mimari bir Android uygulaması üzerinde gerçeklenmiştir. Bu mimari yardımı ile telefona ulaşan mesajlar kişisel, ticari, otp kodları, hatırlatıcı ve istenmeyen adı altında 5 farklı kategoriye ayrılmaktadır. Önerilen mimari Kara Liste, Regex, Makine öğrenmesi ve Beyaz Liste süzgeçlerinden oluşmaktadır. Makine öğrenmesi süzgecinde Naive Bayes, Bayes Net, J48 ve Random Forest algoritmalarının performansları incelenmiştir ve Random Forest \%87'lik başarısı nedeniyle uygulamada tercih edilmiştir. Önerilen çok katmanlı yapı sayesinde mesaj sınıflandırma süresi azaltılırken sınıflandırma başarısı \%93'e yükseltilmiştir. Ayrıca başarının yükseltilmesinde seçilen özellikler ve Zemberek kütüphanesinin kullanımı ile kelimelerin türlerinin ve köklerinin elde edilmesi önemli rol oynamıştır.

Anahtar Kelimeler: Türkçe SMS Sınıflandırma, Çok Katmanlı Süzgeçleme Mimarisi, Mobil Uygulama, Kara ve Beyaz Liste, Kurallı İfadeler, Makine Öğrenmesi

\begin{abstract}
The short message service is one of the most commonly used communication channels. Increasing number of short messages that are used for many different purposes including personal, advertising, promotion, event notification, sales approval, etc. makes it difficult to keep track of messages and to find the target message quickly in the message box. On the other hand, another impotant problem is the spam messages filling the message box unneccasserily. In this study, a novel Multi-tier Filtering Architecture is proposed to classify Turkish Short Messages and to create a smart SMS box. This architecture is also implemented on an Android application. Received messages and old messages are divided into 5 different categories under personal, commercial, otp codes, reminders and spam messages with the help of the proposed architecture. This architecture consists of 4 tiers including Black List, Regex, Machine Learning, and White List filters. The performance of Naive Bayes, Bayes Net, J48 and Random Forest algorithms were examined and Random Forest was preferred for mobile application due to its success of $87 \%$. Thanks to the proposed multi-tier system architecture, the classification success rate has been increased to $93 \%$ while the message classification time is reduced. In addition, the selected features, the use of the Zemberek library and the acquisition of the types and roots of the words within the message played an important role in the promotion of success.
\end{abstract}

Keywords: Turkish SMS Messages, Classification, Multi-tier Filtering Architecture, Mobile Application, Black and White List, Regex, Machine Learning 


\section{GíRiş}

Mobil haberleşmede en yaygın kullanılan iletişim biçimlerinden bir tanesi kısa mesaj servisidir (SMS - Short Message Service). SMS mesajlarının kullanımının yaygınlaşması mesajların niteliklerini ve tiplerini arttırmıştır. Günümüzde SMS kişisel mesajlaşmaların yanı sıra; pazarlama, mobil doğrulama, kargo takip hizmetleri ve bankacılık işlemleri gibi birçok alanda kullanılmaktadır.

Kısa mesaj servisi ucuz ve kullanımı kolay olması sebebi ile duyuru, reklam, promosyon gibi ticari içeriklerin dağıtılmasında kullanılan yöntemlerin başında gelmektedir. Telefon numaraları kişiye mahsus ve benzersiz olduğu için firmalar güvenlik ve doğrulama kodlarını SMS olarak göndermektedir. Toplantı, uçuş vb. birçok etkinliği organize eden şirketler bilet örneklerini kullanıcılara SMS yoluyla ulaştırmaktadır. Aynı zamanda kurumlar yaklaşan etkinliklerini kısa mesajlar ile kullanıcılarına hatırlatmaktadır. SMS gelen kutusuna düşen farklı nitelikteki mesaj sayısının artması, kullanıcının mesajlarını takip etmesini ve yönetmesini gün geçtikçe zorlaştırmaktadır.

Günümüz yaşam şartlarında zamanın etkin ve verimli kullanılması kaçınılmaz hale gelmiştir. İnsanlar zamanı etkin kullanmaya gayret etmekte, zamandan tasarruf edebilecekleri hizmetleri talep etmekte ve bu hizmetlere para harcamaktadır. Örneğin e-posta araçlarından Gmail ve Outlook; e-postaları sosyal, önemsiz, tanıtım gibi başlıklar altında sınıflandırarak elektronik postaların kullanım ve erişim kolaylığını arttırmaktadır. E-postalar gibi SMS'lerin de kategoriler altında sınıflandırılması, SMS hizmetini kullananlar için kolaylık ve zaman tasarrufu sağlayacaktır.

Literatürde yapılan çalışmalar incelendiğinde, mesajları ve e-postaları sınıflandırma işleminin çeşitli makine öğrenmesi algoritmaları ve doğal dil işleme yöntemleri kullanılarak oluşturulan tek veya çok katmanlı mimariler ile sağlandığı gözlenmektedir. Literatürde, e-postaların farklı kategoriler altında sınıflandırılması probleminin çözümü için çok sayıda çalışma [1,2] bulunmasına rağmen, kısa mesajların sınıflandırılmasına yönelik problem için yapılan çalışmalar sınırlı sayıdadır.

Kısa mesajların sınıflandırılması hakkında Healy, Matt [3] ve arkadaşlarının yaptıkları çalışmada Destek Vektör Makineleri ve Naive Bayes sınıflandırıcılar kullanılarak karar tabanlı sinıflandirıcılar oluşturulmuştur. Najadat [4] ve Joe [5] yaptıkları çalışmalarda kısa mesaj gövdelerinden oluşturdukları sözcük vektörlerine göre kısa mesajları sınıflandırmışlardır. Mahmoud ve Ahmet [6] oluşturdukları yapay bağışıklık sistemi ile istenmeyen (spam) kısa mesaj olan ve olmayan mesajları sınıflandırmışlardır. Deepshikha ve Monika [7] yapay sinir ağları yardımı ile kısa mesajları önceden belirlenmiş
Şaka, festival ve istenmeyen gibi kategorilere ayırmışlardır. Ghayda ve Hind [8] vektör uzay modeli ve TF-IDF tekniğini temel alarak kısa mesajları önceden belirlenmiş kategoriler (durumlar, tebrik, arkadaşlık ve satış) altında sınıflandırmışlardır. Parimala [9] yaptığı çalışmada doküman frekans eşik değerini ve Destek Vektör Makinelerini kullanarak s1nıflandırma işlemini gerçekleştirmiştir. Deng vd. [10] tarafindan yapılan çalışmada, Naive Bayes sınıflandırıcısı kullanarak kullanıcı cihazında sınıflandırma yapılmasını sağlamıştır. Geliştirdikleri sistem kullanıcının girdilerine göre kendi-kendini eğitmekte ve bu sayede eğitim verileri sürekli güncel tutulmaktadır. Dipak [11], çalışmasında J48, Naive Bayes gibi farklı algoritmaları karşılaştırarak istenmeyen kısa mesajları filtrelemiştir. Kuruvilla [12] yaptığı çalışmada popüler istenmeyen mesaj filtreleme tekniklerini karşılaştırmalı olarak incelemiştir. Bahsedilen çalışmalarda kullanılan veri setleri ve çıkartılan özellikler İngilizce içerikli mesajların sınıflandırılmasına yönelik uygulamalardır. Türkçe yapılan çalışmalarda da İngilizce için kullanılanlara benzer teknikler kullanılmıştır ancak dillerin farklı olması sebebiyle metinlerden çıkartılan özellikler değişmiştir. Uysal ve arkadaşlarının [13] yaptığı çalışmada Türkçe kısa mesajları içeriklerine göre etkin öznitelik seçme ve örüntü sınıflandırma yöntemlerini kullanan bir süzgeç geliştirilmiştir. Esma vd. [14] kara liste, beyaz liste ve anlamsal/biçimsel özellikler katmanlarından oluşan üç katmanlı hibrit mesaj filtreleme mimarisi ile istenmeyen ve normal mesajları birbirinden ayıran sınıflandırma işlemini gerçekleştirmişlerdir.

Bu çalışmada, bahsedilen diğer çalışmalardan farklı olarak, hem beyaz liste/kara liste yaklaşımını hem tarih/otp (Tek Kullanımlık Şifre - One Time Password) kodları ön-süzgeçlerini içeren hem de kısa mesaj içeriklerini biçimsel ve anlamsal yönleri ile değerlendirerek sınıflandırmayı gerçekleştiren bir mimari önerilmektedir. Önceki çalışmalarda mesajlar genellikle "istenmeyen" ve "normal" olarak iki sınıfa ayrılırken, bu çalışmada kısa mesajlar kişisel, hatırlatıcı, ticari, otp kodları ve istenmeyen olmak üzere toplamda beş kategori altında sınıflandırılmaktadır. Ön süzgeçlerin oluşturulmasında tarih ve otp kodlarını algılayan Regex'ler (kurallı ifadeler) kullanılmaktadır. Beyaz/kara liste ve ön süzgeçlerin kullanılmasıyla makine öğrenmesi modeline iletilen SMS sayısı azaltılmıştır. Kara listede bulunan numaralardan gelen veya gövdesinde kara listede bulunan kelimeleri bulunduran k1sa mesajlar sinıflandırma filtresine gönderilmeden "istenmeyen" mesaj olarak değerlendirilmektedir. Aynı şekilde bahsedilen ön-süzgeçler yardımı ile içerisinde zaman ifadesi içeren mesajlar "hatırlatıcı", otp kodu bulunduran kısa mesajlar “otp” olarak değerlendirilmektedir.

Mesajların biçimsel ve anlamsal özelliklerine göre s1nıflandirılmasında Naive Bayes, Bayes Net, J48 ve Random 
Forest algoritmalarının performansları incelenmiştir. Analizler sonucunda başarımı en yüksek Random Forest sınıflandırma yöntemi tercih edilerek kısa mesajları sınıflandıran bir Android mobil uygulaması geliştirilmiştir.

Önerilen sistem mimarisi Şekil 1'de ifade edilmiştir. Şekil 1'de sarı ile çevrelenmiş alan çok katmanlı süzgeçleme mimarisinin sınırlarını ifade etmektedir. Çok katmanlı süzgeçleme mimarisine ulaşan kısa mesajlar filtrelenerek ait olduğu sınıfa karar verilmektedir. Elde edilen sınıf bilgisi ile birlikte kısa mesaj uygulama veri tabanına kaydedilerek uygulama arayüzünde listelenmeye hazır hale gelmektedir.

“Çok katmanlı Süzgeçleme Mimarisi” başlığında çok katmanlı sinıflandırma mimarisinden ve alt başlıklar halinde mimarinin süzgeçleme katmanlarından bahsedilmiştir. "Uygulama" başlı̆̆ ile tasarlanan mimarinin Android ortamında gerçeklenmesi ile geliştirilmiş uygulama genel hatlarıyla tanıtılmıştır. "Performans Analizi" kısmında adım adım yapılan çalışmaların sonuçlara etkisi irdelenmiştir. "Uygulama Metrikleri" bölümünde sistemin genel performansının karşılaştırmalı analizine yer verilmiştir. "Sonuç" bölümünde elde edilen çıtıllar yorumlanmış, sistem genel hatlarıyla özetlenmiştir.

\section{II. Çok Katmanlı Süzgeçleme Mimarisi}

Önerilen çok katmanlı mesaj süzgeçleme mimarisi ile cihaza ulaşan mesaj dört farklı süzgeçten geçirilmektedir. Süzgeçleme mimarisine giren kısa mesajın önce kara listede olup olmadığı kontrol edilmektedir. Eğer kısa mesajın göndereni veya mesaj içeriğindeki bir kelime kara liste içerisinde bulunuyorsa mesaj “istenmeyen" olarak etiketlenmektedir.
Bu aşamayı geçen kısa mesaj henüz etiketlenmemiş ise mesaj içerisinde OTP kodları ve tarihler ile eşleşen Regex'lerin bulunduğu diğer bir filtreye tabii tutulur. Eğer mesaj içeriğinde Regex'ler ile bir eşleşme varsa mesaj ilgili olduğu Regex'in s1nıfiyla, "otp" veya "hatırlatıcı", olarak etiketlenmektedir.

Önceki iki süzgece de takılmadan ilerleyebilmiş bir kısa mesaj var ise mesajın sinıf bilgisi Random Forest algoritması ile oluşturulmuş sınıflandırma modeli çalıştırılarak elde edilmektedir. Beyaz liste yaklaşımı da modelin çalışmasının ardından devreye girmektedir. Belirlenmiş koşullara uygunluk durumunu değerlendiren bu yaklaşıma ilerleyen paragraflarda değinilmiştir. Çok katmanlı süzgeçleme sayesinde sınıflandırma algoritmasının çalıştırılma sayısı azaltılmıştır. Önerilen çok katmanlı süzgeç mimarisinde kullanılan algoritmanın akış diyagramı Şekil 2'de ifade edilmiştir.

\subsection{Kara Liste Süzgeci}

Ön süzgeçleme yöntemlerinden biri olan kara ve beyaz liste yöntemi anahtar kelime bazlı filtreleme uygulamalarında sıkça kullanılan yöntemlerden biridir. Bu yöntemde kullanıc1, beyaz (güvenli) ve kara (istenmeyen) olarak tanımlanan iki sınıf için kelime listelerini oluşturur.

Herhangi bir metin kara liste süzgecinden geçirilmek istendiğinde metnin içerdiği tüm kelimeler "kara liste" elemanları ile karşılaştırılır, eğer metin kara liste elemanlarından birini ya da birkaçını içeriyorsa "kara liste" süzgeci pozitif çıktı üretir. Negatif çıktı ise metin içerisinde herhangi bir kara liste elemanının bulunmaması sonucunda üretilir.

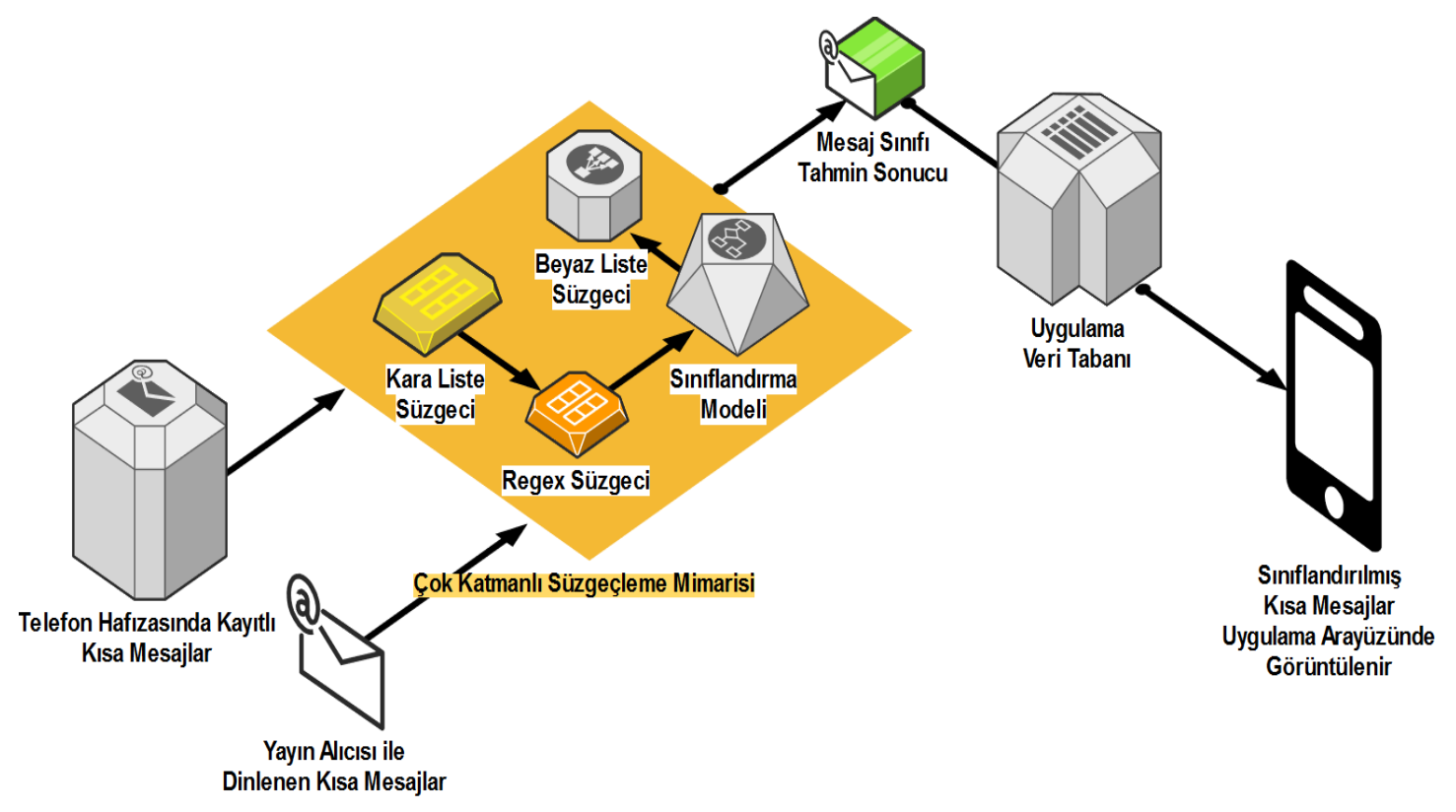

Şekil 1. Sistem Mimarisi 


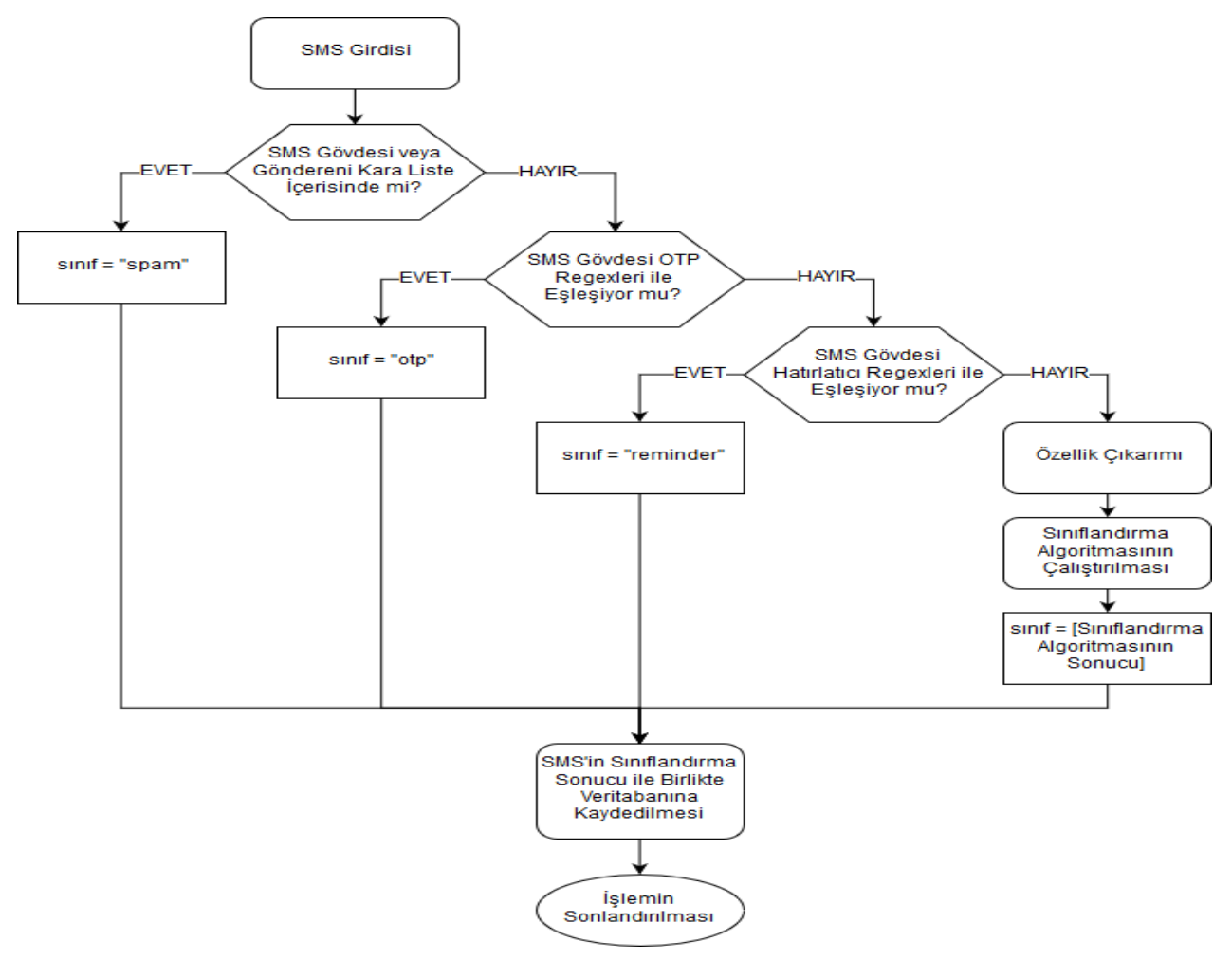

Şekil 2. Süzgeçleme Mimarisinin Akış Diyagramı

\subsection{Regex ile OTP ve Hatırlatıcı Süzgeci}

Metin içerisinde belirli bir dizilimde bulunan ancak içerikleri farklı olabilen birtakım kelimeler bulunabilir. Örneğin tarihler zaman dilimi ifade edebilir ancak sunumları 24.03.1997 ya da 11/04/2024 gibi farklı şekillerde olabilir. Benzer problemler ile SMS sınıflandırma sürecinde karşılaşılmaktadır. Bankaların onay kodları, kargo takip numaraları ve tarih hatırlatıcıları gibi formatı aynı ancak içeriği farklı olan SMS'lerin sınıflandırılması "Regex"ler yardımı ile hızlı bir şekilde yapılabilir.

Regex'ler metin içerisinden belli kurallara uyan alt metinler elde etmek için kullandığımız bir yöntemdir. Metin içerisinde geçen yararlı özellik niteliğindeki düzenli alt metinlerin sınıflandırma modeli çalıştırılmadan süzgeçlenmesi sistem performansına olumlu katkı sağlayacaktır. Bu sebeple sistem mimarisine ara katman olarak Regex temelli "hatırlatıcl" ve "otp kodlarl” süzgeçleri eklenmiştir.

"Hatırlatıcl" Regex'i ile tarih ifade eden mesajlar süzgeçlenerek "hatırlatıcı" sınıfında uygulama veri tabanına kaydedilmektedir. Benzer şekilde "otp kodu” Regex formatları ile eşleşen bir kısa mesaj ile karşılaşıldığında mesajın sinifi "otp kodu" olarak etiketlenmektedir. Tarih yazımlarındaki 24.03.2018, 24/03/2018 gibi farkl1lıklar, otp kodlarındaki biçimsel farklılıklar göz önünde bulundurularak her süzgeç için sık kullanılan formatlar incelenmiş ve tespit edilen formatlar ile eşleşen Regex'ler geliştirilip sisteme entegre edilmiştir.

\subsection{Kısa Mesajların Makine Öğrenmesi Yöntemleri ile Sinıflandırılması}

Mesajların farklı kategoriler altında sınıflandırılarak organize edilmesi bir metin sınıflandırma problemidir. Sistem girdi olarak SMS mesajı almakta ve mesajın etiket bilgisini "kişisel", "ticari”, "hatırlatıcl", "otp kodlarl" ve "istenmeyen" olarak tespit etmektedir.

Çok katmanlı bir sınıflandırma mimarisinin gerçeklenebilmesi için, veri setinin toparlanması, ön işlemlerden geçirilmesi ve özellik çıkarımı gibi izlenmesi gereken adımlar bulunmaktadır. Önerilen çok katmanlı sınıflandırma mimarisini gerçeklerken Şekil 3'te ifade edilen yol haritası izlenmiştir.

Gönüllü kısa mesaj sağlayıcılardan elde edilen mesajlar ayıklama, özellik seçimi gibi ön işleme aşamalarına tabii tutulmuş, ardından algoritmaların veri seti üzerindeki başarımlarını ölçebilmek için çeşitli testler gerçekleştirilmiştir. Yapılan testler sonucunda en güvenilir algoritma belirlenmiş ve model çıktısı alınmıştır. Sonuçların gerçek zamanlı ölçülebilmesi ve sınıflandırma modelini kullanıcıya ulaştırabilmek için bir Android uygulaması geliştirilmiştir. 


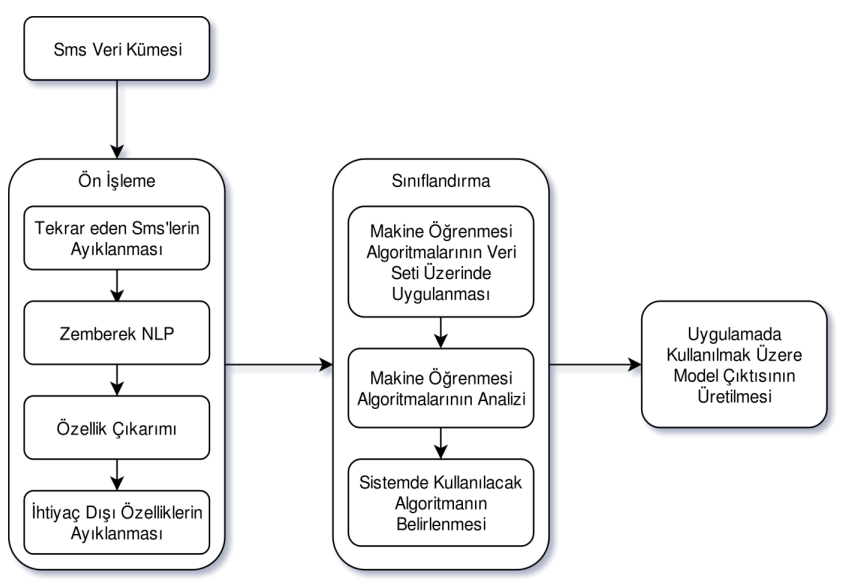

Şekil 3. Sistemin Oluşturulması Sırasında İzlenen Temel Adımlar

\subsubsection{Veri setinin oluşturulması}

Metinlerin sınıflandırılabilmesi için eğitim ve test veri kümelerine ihtiyaç duyulmaktadır. Veri kümesini oluşturabilmek için 11 kişiden 2402 adet kısa mesaj toplanmıştır. Kişilerden çalışma kapsamında kısa mesajlarının alınmasına ve gerçekleştirilecek tüm akademik çalışmalarda kullanılmasına dair onay alınmıştır. Benzerlik gösteren veya aynı kısa mesajlar elenerek mesaj sayısı 1780'e düşürülmüsstür. Ardından mesajlar incelenerek önceden belirlenmiş "kişisel", "ticari", "hattrlatıcl", "otp kodlarl" ve "istenmeyen" etiketleriyle etiketlenmiştir.

Tablo 1. Mesaj Sinıfları ve Bulundurdukları Mesaj Miktarları

\begin{tabular}{lll}
\hline Mesaj Sınıfı & Miktar & $\mathbf{\%}$ \\
\hline Kişisel & 839 & 47,13 \\
\hline Ticari & 245 & 13,76 \\
\hline Otp Kodları & 132 & 7,41 \\
\hline Hatırlatıcı & 510 & 28,65 \\
\hline İstenmeyen & 54 & 3,03 \\
\hline
\end{tabular}

\subsection{2 Örnek mesajlar}

Mesaj tiplerinin öne çıkan karakteristik özellikleri bulunmaktadır. Örneğin "hatırlatıcı" tipindeki mesajlarda "bilet" ve "toplantı" kelimeleri çokça kullanılmakta, "ticari" tipteki mesajlarda ise "kampanya" ve "hediye" kelimeleri öne çıkmaktadır. Ayrıca biçimsel olarak incelendiğinde "istenmeyen" mesajların içeriğinde büyük harf oranının daha fazla olması gibi biçimsel-karakteristik özellikler de bulunmaktadır. Tablo 2'de her mesaj tipi için örnekler sunulmuştur. Sunulan örneklerde bazı şirket isimleri ve özel veriler değiştirilerek bilginin gizliliği sağlanmaya çalışılmıştır Bir sonraki bölümde mesajların sınıflandırılabilmesi için yapılan özellik çıkarımı çalışmaları detaylandırılacaktır.

Tablo 2. Sınıflar için Örnek Mesajlar

\begin{tabular}{|c|c|c|}
\hline Mesaj Sinıfı & Mesaj Gövdesi & Gönderen \\
\hline Kişisel & Merhaba, nasilsin? & 551.123 .4567 \\
\hline Kişisel & $\begin{array}{l}\text { Dün derste aldığın notların fotoğrafını } \\
\text { gönderebilir misin? }\end{array}$ & A. Yiğit İlkadam \\
\hline Hatırlatıc1 & $\begin{array}{l}\text { Merhaba Adem Bey, ABS filmine } \\
24.03 .2019 \text { tarihine almış olduğunuz } \\
\text { bilet onaylanmıştır. Keyifli seyirler } \\
\text { dileriz. B125 }\end{array}$ & OMNIA \\
\hline Hatırlatıc1 & $\begin{array}{l}\text { Merhaba Adem, Haftaya cuma ( } \\
\text { 24/03/2020) tarihine düzenlediğimiz } \\
\text { toplantıya katılman ekibimizi gurur- } \\
\text { landıracaktır. }\end{array}$ & Farl \\
\hline Ticari & $\begin{array}{l}\text { Süpper Kampanya!! Atikali Petrol- } \\
\text { lerinden yapacağını 100TL ve üzeri } \\
\text { alışverişlerinizde 20TL market harca- } \\
\text { ması hediye! }\end{array}$ & $\begin{array}{ll}\text { ATiKALİ } & \text { PET- } \\
\text { ROLLERİ } & \end{array}$ \\
\hline Ticari & $\begin{array}{l}\text { Sana özel promosyon bu ay sonuna } \\
\text { kadar yapacağın ilk } 2 \text { sürüş } \% 20 \text { indi- } \\
\text { rimli. Ayrıntılı bilgi : ubr.com/flasdw }\end{array}$ & Uber \\
\hline Otp Kodlar1 & $\begin{array}{l}\text { Değerli Müşterimiz, 24.03.2018 tari- } \\
\text { hinde yapmış olduğunuz 1223TL de- } \\
\text { ğerindeki alsşverişinizi tamamlama- } \\
\text { nız için doğrulama kodunuz : A34sfS } \\
\text { Keyifli alışverişler dileriz. B125 }\end{array}$ & JET \\
\hline Otp Kodları & $\begin{array}{l}\text { Satış Bilgileri : 09.02.2019 18:00 IS- } \\
\text { TANBUL-ESKISEHIR YHT PNR } \\
\text { No : S15 6QWE549 (65 TL) İyi yol- } \\
\text { culuklar dileriz... TCDD Taşımacı- } \\
\text { lik A.ş }\end{array}$ & TCDD EYBIS \\
\hline İstenmeyen & $\begin{array}{l}\text { KAMPANYA!!! HEMEN AL, HA- } \\
\text { YATINA SAĞLIK KAT! go.gl/ } \\
\text { as46dw58 }\end{array}$ & .9999 \\
\hline İstenmeyen & $\begin{array}{l}\text { ANTALYADA DENIZE SIFIR LUX } \\
\text { DAIRE VE YAZLIKLAR BU SE- } \\
\text { ZONA OZEL \%50 YE VARAN INDI- } \\
\text { RIMLI FIYATLARLA. KACIRMA- } \\
\text { YIN : http://tinyurl.com/asdwllmm }\end{array}$ & $\begin{array}{l}\text { ANTALYA BE- } \\
\text { ACH }\end{array}$ \\
\hline
\end{tabular}

\subsection{3 Özellik çıkarımı}

Mesajların karakterini belirleyen mesajın göndereni, gönderim zamanı, büyük/küçük harf frekansı, kaç kelimeden oluştuğu vb. biçimsel birçok özellik bulunmaktadır. Aynı zamanda mesajın karakteristiğini belirleyen anlamsal özelliklerinin de göz önünde bulundurulması gereklidir. Anlamsal özelliklerin çıkarımı için Türkçe için geliştirilmiş doğal dil işleme kütüphanesi olan Zemberek kullanılmıştır. Zemberek yardımıyla cümle içerisindeki kelimelerin tipleri $(k e-$ lime, kısaltma, email, url ve tarih) belirlenmiştir. Kelimeler köklerine ayırılarak "kampanyalar" ve "kampanyası" gibi kelimelerin aynı kelime olduğu algılanmaktadır. Tablo 4'te, 
başlangıçta yapılan çalışmalar sonucu belirlenen özellikler ve tanımları bulunmaktadır.

Kısa mesaj içerisinde URL, E-posta adresi, tarih gibi içerik olarak farklı olan ancak ifade ettiği tip aynı olan simgeler (token) bulunabilir. Örneğin ";" (noktalı virgül) karakteri de bir noktalama işaretidir, "!” (ünlem işareti) de bir noktalama işaretidir. Kelime vektörlerini oluştururken “*” ve "!" gibi aynı tipteki simgelerin tip ismi ile kullanılması özellik seçiminde noktalama işaretlerinin sınıf belirlemedeki etkisini göstermesini sağlayacaktır.

Simgelerin yerine simge tiplerinin sonuçlara etkisini inceleyebilmek için yeni bir yaklaşım geliştirilmiştir. Bu yaklaşımda oluşturulacak "roots" özelliği için tipi "kelime" olan simgeler kelimenin kökü çıkarılarak, tipi "kelime” olmayan tüm simgeler ise simge tipi ile kaydedilmektedir. Örneğin "Çantamda" simgesi bir kelimedir, "çanta" olarak değerlendirilecektir. Ancak "24.03.2019" simgesi kelime değil, bir tarihtir. Dolayısıyla bu simge yerine simgenin tipi olan "DATE" yazılacaktır. Bahsedilen simge değerlendirme yaklaşımı Tablo 3’te örneklenmiştir.

Tablo 3. Simge Değerlendirme Yaklașımı Örneği

\begin{tabular}{ll}
\hline Girdi (SMS Gövdesi) & Çıktı(Kökler) \\
\hline "Kampanya 30.01.2018 tarihine ka- "kampanya DATE tarih kadar \\
dar 'B3SEW4' kodu ile indirimli alış- & WORDWITHAPOSTROPHE \\
veriş şansı : http://www.abcd.com" & kod indirim alışveriş şans URL" \\
\hline "Merhaba, 07.05.2016* TARIHINDE & "merhaba DATE PUNCTUA- \\
YAPTIGINIZ ALISVERISTEN GA- & TION tarih yap alışveriş galaxy \\
LAXY 'S5' CEP TELEFONU KA- & WORDWITHAPOSTROPE cep \\
ZANDINIZ HEDIYENIZI AL- & telefon kazan hediye al için he- \\
MAK ICIN HEMEN ARAYIN & men ara NUMBER WORDWIT- \\
021.296.70098 B364" & HAPOSTROPE “ \\
\hline
\end{tabular}

Her bir mesaj örneği için yukarıdaki özellik çıkarımlarının yapılmasının ardından WEKA kütüphanesinin sağladığı StringToWordVector filtresi yardımı ile yeni özelliklerin ç1karımında bulunulmuştur. StringToWordVector [15], String özniteliklerini, bir dizi metinden elde edilmiş özelliklere dönüştüren bir filtredir. Yeni özellikler filtrelenmiş sözcüklerden oluşmaktadır.

\subsubsection{Sinıflandirma}

Çalışma kapsamında Naive Bayes, Bayes Net, J48 ve Random Forest algoritmaları veri seti üzerinde çalıştırılmış ve elde edilen sonuçlar kıyaslanmıştır. Sınıflandırma çalışması yapılırken özelliklerin sonuçlara etkisini incelemek için yeni özellikler eklenerek modeller tekrar test edilmiştir. Doğrulama yöntemi olarak k katlamalı çapraz doğrulama (k-fold cross validation) kullanılmıştır ve yöntemdeki $\mathrm{k}$ değeri 10 olarak belirlenmiştir.

Naïve Bayes [16] bir sınıflandırma/kategorilendirme algoritmasıdır ve Bayes Teoremine dayanan bir sınıflandırma tekniğidir. Basit bir ifadeyle, bir Naive Bayes sınıflandırıcı, bir sınıftaki belirli bir özelliğin varlığının başka herhangi bir özelliğin varlığına bağlı olmadığını varsayar. Örneğin, bir meyve yeşil, yuvarlak ve çapı yaklaşı $10 \mathrm{~cm}$ ise bir karpuz olarak düşünülebilir. Bu özellikler birbirlerine veya diğer özelliklerin varlığına bağlı olsa bile, bu özelliklerin tümü, bu meyvenin bir karpuz olması olasılığına bağımsız olarak katkıda bulunur ve bu yüzden "Naif" olarak bilinir.

Bayes Net [17], veriden modeller oluşturmak için kullanılabilen bir olasılıksal grafik modeli türüdür. Tahmin, belirsizlik algılama, tanılama, otomatik iç görü, akıl yürütme, zaman dizisi tahmini ve belirsizlik altında karar verme gibi çok çeşitli görevlerde kullanılabilirler. Bayes Net, bir dünyanın modellenen bir kısmının durumlarını yansitır ve bu durumların olasıl1kklarla nasıl bağlantılı olduğunu anlatır. Örneğin, araba motoru normal çalışıyor veya sorun veriyor olabilir, vücudunuz hasta veya sağlıklı olabilir.

J48 [18][19], bir karar ağacı algoritmasıdır. Karar Ağacı algoritmaları, özniteliklerin - birtakım örnekler için davranış biçimlerini bulmayı sağlar. Bu algoritmalar, hedef değişkenin tahmin edilmesi için kurallar üretir. Ağaç sınıflandırma algoritması yardımıyla verilerin kritik dağılımı kolayca anlaşılabilir. C4.5 algoritmasının açık-kaynak JAVA gerçeklemesi olan J48 algoritması ID3'ün bir uzantısıdır. J48 ek olarak eksik değerler, karar ağaçları budaması, sürekli öznitelik değer aralıkları, kuralların türetilmesi gibi birtakım özellikleri bulundurmaktadır.

Random Forest [20], hiper-parametreli ayar yapmadan bile, çoğu zaman iyi bir sonuç üreten, esnek, kullanımı kolay bir makine öğrenmesi algoritmasıdır. Aynı zamanda en çok kullanılan algoritmalardan biridir, çünkü hem kullanımı kolaydır hem de sınıflandırma ve regresyon görevleri için kullanılabilir.

\subsection{Beyaz Liste Süzgeci}

Sistemin son katmanı olan "Sinıflandırma Modeli" katmanına yardımcı olarak tasarlanmış bu katman, sınıflandırma modelini sonucunu inceleyerek koşullu çıktılar üretmektedir.

Örneğin: Hiçbir süzgece takılmadan sınıflandırma modelinin çalıştırıldığı katmana kadar gelebilen dört kısa mesaj 
"A", "B", "C" ve "D" kısa mesajları olarak adlandırsın. A kısa mesajının içeriği hatırlatıcı olsun, B'nin içeriği istenmeyen kısa mesaj özelliği göstersin. C kısa mesajı da kişisel kısa mesajların özelliklerini barındırsın. D kısa mesajı ise içerisinde ticari nitelikte öğeler bulundursun.

A, B, C ve D mesajlarını telefon rehberinde kayıtlı, yani beyaz liste içerisinde değerlendirilecek bir kişinin gönderdiğini varsayalım. Bu durumda mesajların kişisel olarak mı etiketlenmesi gerekir, yoksa tahmin edilen etiketi ile mi? Bu karışıklığın önüne geçebilmek için makine öğrenmesi modelinin yaptığı tahmini belirli parametreler ile kontrol edilerek sonuç iyileştirilmeye çalışılmıştır.

Model kısa mesajın etiketini tahmin ettikten sonra üç şey kontrol edilir: "Mesaj göndereni kayıtlı mı?”, "Modelin tahmin ettiği etiket 'hatırlatıcı' mı?" ve "Modelin tahmin ettiği etiket 'otp kodu' mu? ”. Eğer gönderen kayıtlı ise ve tahmin edilen etiket "hatırlatıcı" ise A mesajında olacağı gibi mesajın etiketi "hatırlatıcı" olacaktır. Çünkü hatırlatıcı özelliği kişisel özelliğine baskın gelmiştir. Aynı şekilde, gönderen kayıtlı ve tahmin edilen etiket "otp kodu" ise sonuç “otp kodu” olacaktır. Ancak "hatırlatıcl” ve "otp kodu” sınıflarının dışında rehberde kayıtlı bir kişinin ticari veya istenmeyen mesaj atmış olması düşünülemez. Bu sebeple B ve D mesajlarının sınıflandırma sonuçlarında olacağı gibi sınıflandırma sonucu "kişisel”" olacaktır. C mesajı ise zaten "kişisel" özellikleri barındırdığ 1 için model tahmini de kişisel olacak, rehberde kayıtlı olması ile "kişisel" mesaj olduğu teyit edilecektir.

Uygulanan bu yöntemde model çıktı doğruluğunun beyaz liste içeriği ile arttırılması amaçlanmıştır.

\section{UYGULAMA}

Üretilen çok katmanlı süzgeçleme mimarisi Android Studio üzerinde JAVA dili kullanılarak gerçeklenmiş ve bir mobil uygulama geliştirilmiştir. Geliştirilen uygulama mesaj gönderme, alma, okuma ve silme gibi standart özellikleri bulundurmakla birlikte cihazdaki kısa mesajları sınıflandırılmış bir biçimde kullanıcıya sunmaktadır.
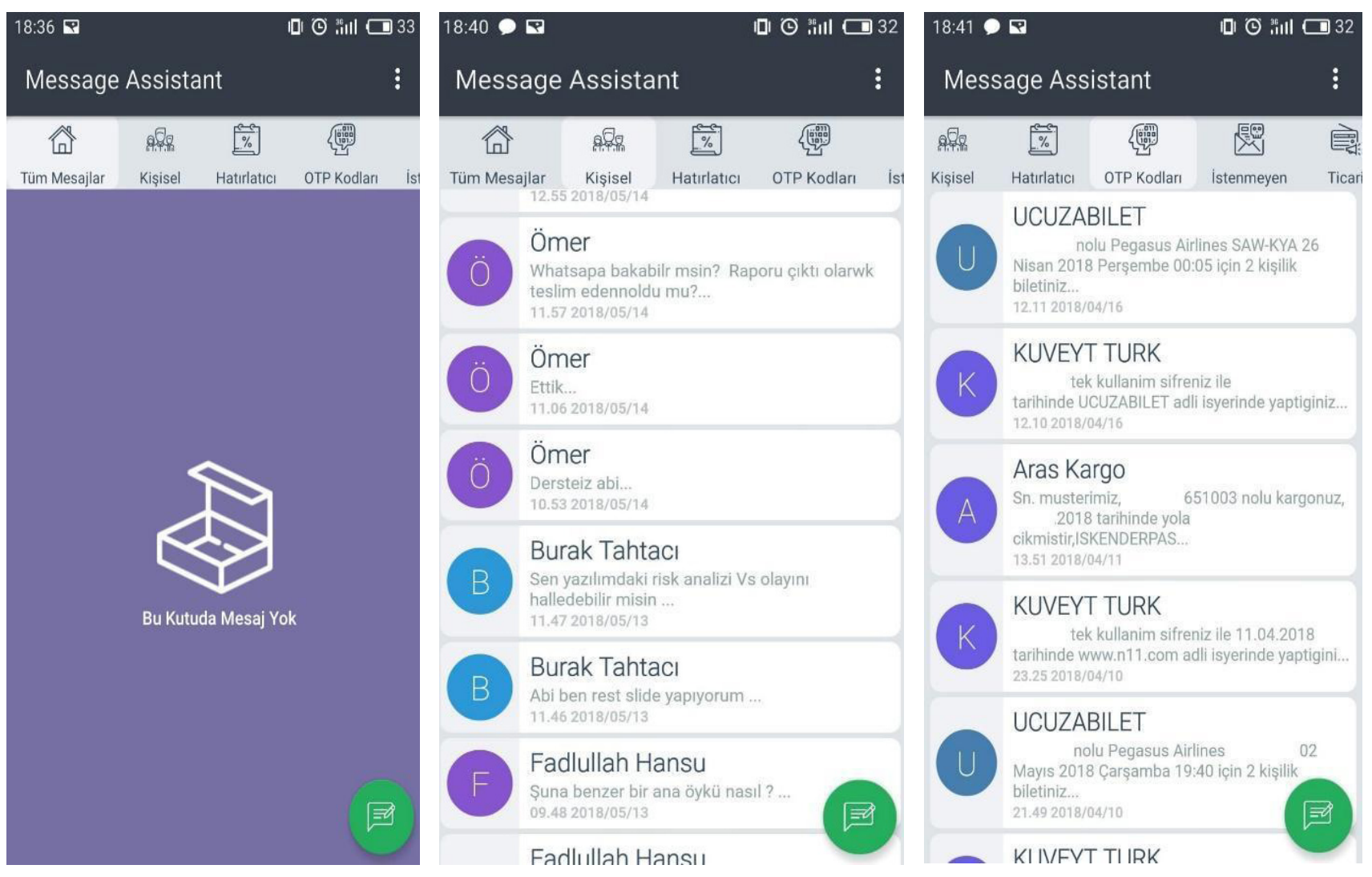

Şekil 4. Uygulama Arayüzü (Mesajların bazı bölümleri bilgi gizliliği gereği maskelenmiştir.) 

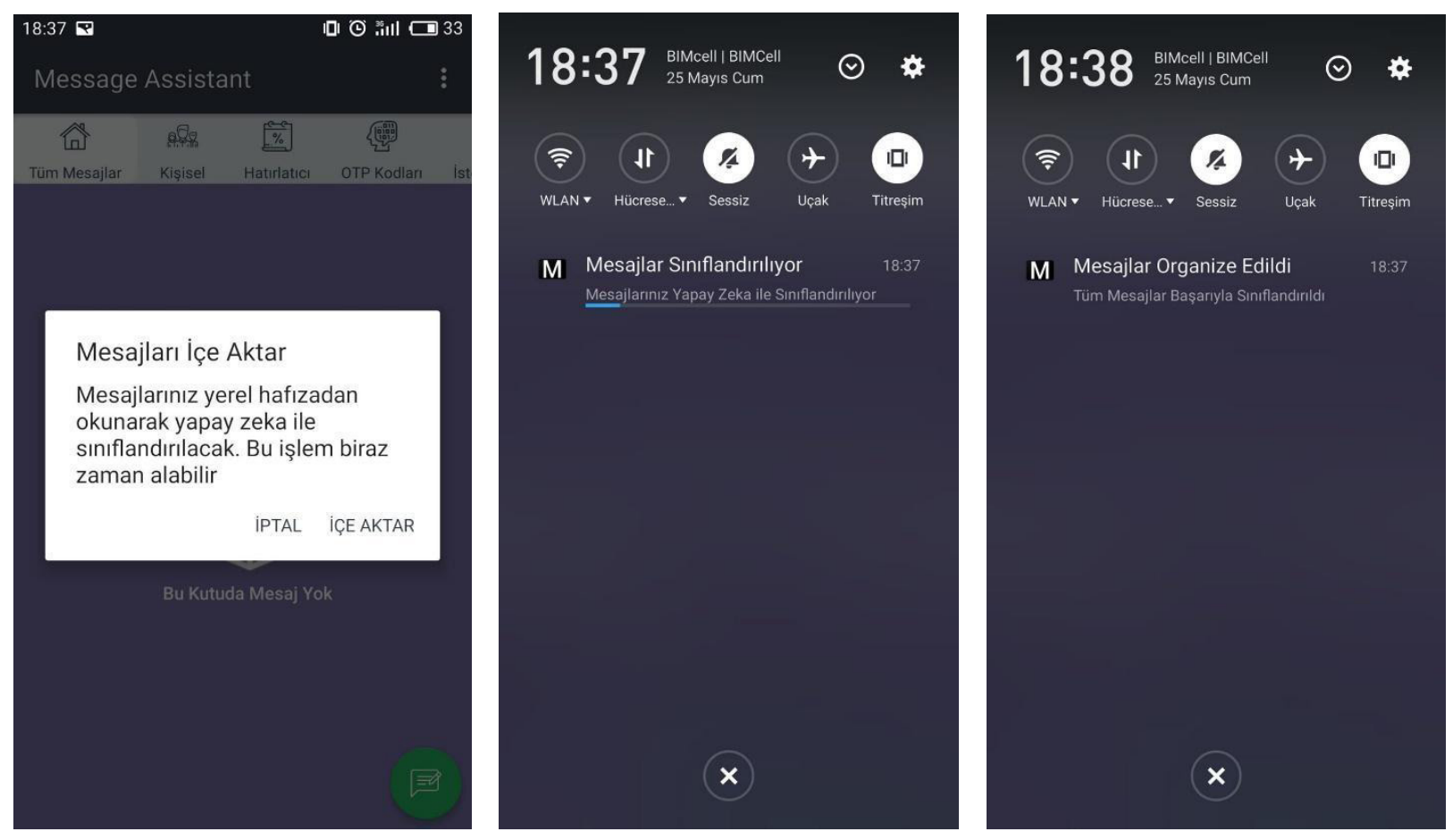

Şekil 5. Geçmiş Mesajların Toplu Bir Şekilde Sınıflandırılması

Şekil 4'de gösterildiği gibi uygulama arayüzünde "Tüm mesajlar", "Kişisel”, "Hatırlatıcı", "OTP Kodları", "Istenmeyen" ve "Ticari" başlıklarında kısa mesajlarını listeleyen ekranlar bulunmaktadır. "Tüm Mesajlar" tüm kısa mesajların birlikte listelendiği bir arayüzdür. "Kişisel" ve diğer ekranlarda ise ilgili kategorideki kisa mesajlar listelenmektedir. Bu ekranlar arasında kaydırarak geçiş yapılabilmesi sağlanmıştır.

Uygulama, bulundurduğu yayın alıcısı (broadcast receiver) ile telefona gelecek mesajları dinlemektedir. Aynı zamanda "İçe aktar" seçeneği ile telefon hafızasında kayıtlı tüm kısa mesajlar okunarak Şekil 5 'te örneklendiği üzere sınıflandırılabilmektedir. Alıcı tarafından yakalanan veya telefon hafizasindan okunan kisa mesajlar çok katmanlı süzgeçleme mimarisine tabii tutularak sınıflandırıldıktan sonra etiketleri ile birlikte uygulama veri tabanına kaydedilmektedir. Yeni mesaj geldiğinde bildirim oluşturularak kullanıcı bilgilendirilmektedir.

Mesajlara uzun süre basıldığında Şekil 6'daki gibi mesaj seçenekleri ekranı çıkmaktadır. Her mesaj tipinde "Sil", "Başka sınıfa gönder" ve "Takvime Ekle" seçenekleri bulunmaktadır. Kullanıcı "başka sınıfa gönder" seçeneği ile mesajı istediği kategoriye gönderebilmekte, "Takvime Ekle" seçeneği ile mesaj için etkinlik planlayabilmektedir. Ayrıca "Hatırlatıcı" ve "OTP Kodları" mesaj tipleri için özelleştirilmiş bazı ek seçenekler bulunmaktadır.

Hatırlatıcı olarak etiketlenmiş kısa mesajların mesaj seçeneklerinde "Takvime Ekle" seçildiğinde geliştirilen Regex yardımı ile mesaj içerisindeki tarih tespit edilmekte ve etkinlik oluşturma arayüzü ilgili tarihe planlanmış olarak açılmaktadır.

"OTP Kodları" olarak etiketlenmiş mesajlarda ise "Kodu Kopyala" seçeneği bulunmaktadır. Bu seçenek sayesinde mesaj gövdesinde bulunan OTP kodları tespit edilip, cihazın geçici taşıma panosuna (clipboard) kopyalanmaktadır.

Kısa mesajlar kullanım alanları gereği sınırlı boyuttaki metin kümelerinden oluşmaktadır. Bir cihaza bir kısa mesaj ulaştığında beraberinde şu bilgileri de bulundurmaktadır:

Zaman Damgası: Mesajın gönderilme zamanına ait bilgi

Gönderen Numarası: Mesajı gönderen tarafin telefon numaras1 veya ismi

Mesaj Gövdesi: Göndericinin ilettiği mesajın içeriği 


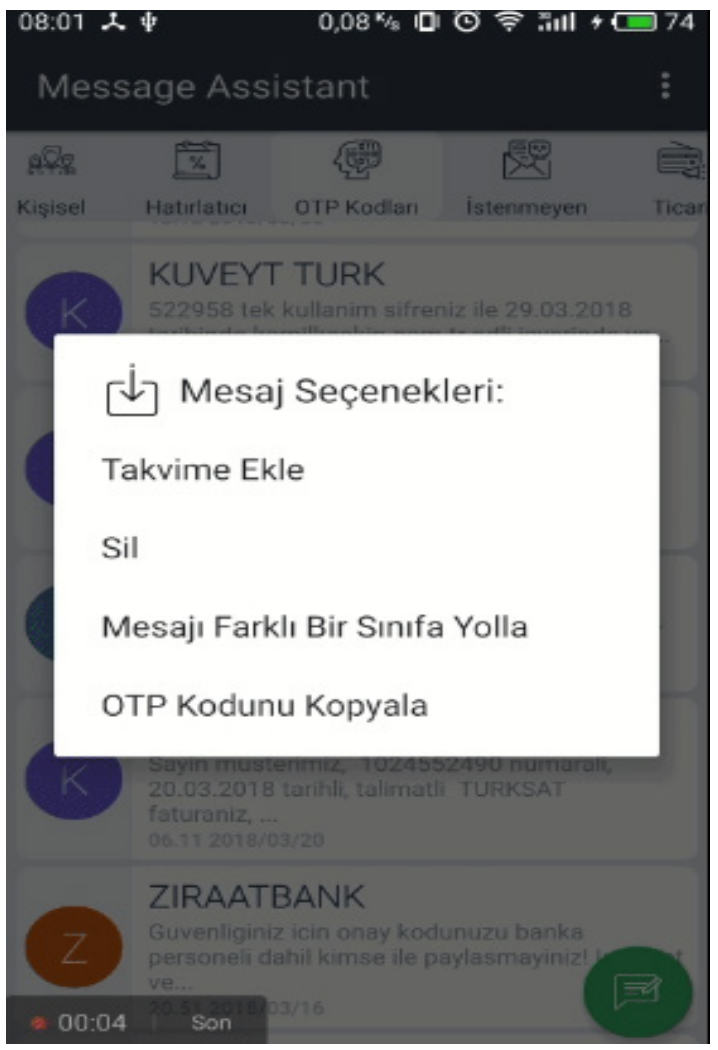

Şekil 6. Mesaj Seçenekleri

\section{PERFORMANS ANALIZI}

Kısa mesajların içerdiği temel bilgilerden yola çıkılarak ne zaman gönderildiği, kimin gönderdiğinin değerlendirilmesi gibi koşulsal sınıflandırma yapılması mümkündür. Ancak metin içerisinden çıkartılabilen anlamsal ve biçimsel özelliklerin elde edilmesi metnin daha doğru bir şekilde daha çok sınıf altında sınıflandırılmasında yardımcı olacaktır.

Metnin sınıflandırılabilmesi için özellik çıkarımına ihtiyaç duyulmaktadır. Bu sebeple bu çalışma altında sınıflandırmaya yönelik özellikler seçilmiş ve özelliklerin sonuçlara etkisi incelenmiştir. "Temel Biçimsel Özellikler" başlığ altında kısa mesaj üzerinden elde edilen biçimsel özelliklerden bahsedilmiş; "adressType ve PartOfDay Özelliğinin Eklenmesi”, "letterCaseNormalization Özelliğinin Eklenmesi" başlıkları altında mesajlardan dolaylı yollarla elde edilmiş yeni biçimsel özelliklerin eklenmesinden bahsedilmiştir. "String2WordVector Filtresinin Kullanılması" başl1ğında ise kelimelerin uzaysal alana yerleştirilmesi ile elde edilen özelliklerden ve bu özelliklerin nasıl elde edildiğinden bahsedilmiştir.

Her bölümde karmaşıklık matrislerine yer verilmemiş bunun yerine özelliklerin neden seçildiği ve beklenen etkisinden bahsedilmiştir. Son bölüm olan "Eklenen Özellikler ile Başarı Değişimlerinin Kıyaslanması" bölümünde ise sistemin genel başarısını özetleyen testler ve sonuçlar irdelenerek karmaşıklık matrisine yer verilmiştir.

\subsection{Temel Biçimsel Özellikler}

Sınıflandırma çalışmalarının başlangıcında temel özellikler tespit edilmiş ve sınıflandırma modelleri ile test edilmiştir. Bu adımda kullanılan özellikler, Tablo 4'te gösterilmiştir.

Tablo 4. Temel Biçimsel Özellikler Tablosu

\begin{tabular}{|c|c|c|}
\hline Özellik & Tipi & Açılama \\
\hline $\begin{array}{l}\text { PercentNu- } \\
\text { meral }\end{array}$ & Nümerik & $\begin{array}{l}\text { Yüzdelik ifade sayısı / Mesajdaki toplam } \\
\text { kelime sayıs1 }\end{array}$ \\
\hline $\begin{array}{l}\text { RomanNu- } \\
\text { meral }\end{array}$ & Nümerik & $\begin{array}{l}\text { Mesajda geçen roma rakamı sayısı / Mesaj- } \\
\text { daki toplam kelime sayıs1 }\end{array}$ \\
\hline URL & Nümerik & $\begin{array}{l}\text { Mesajda geçen URL sayıs1 / Mesajdaki } \\
\text { toplam kelime sayıs1 }\end{array}$ \\
\hline Word & Nümerik & $\begin{array}{l}\text { Mesaj içeriğindeki Zemberek sözlüğünde } \\
\text { bulunan kelime miktarı / Mesajdaki toplam } \\
\text { kelime sayısı }\end{array}$ \\
\hline $\begin{array}{l}\text { Abbreviati- } \\
\text { onWithDots }\end{array}$ & Nümerik & $\begin{array}{l}\text { Mesajda geçen noktalı kısaltma sayısı / } \\
\text { Mesajdaki toplam kelime sayısı }\end{array}$ \\
\hline DateX & Nümerik & $\begin{array}{l}\text { Tarih ifadesi say1s1 / Mesajdaki toplam ke- } \\
\text { lime say1s1 }\end{array}$ \\
\hline Email & Nümerik & $\begin{array}{l}\text { Mesajda geçen e-posta adresi sayıs1 / Me- } \\
\text { sajdaki toplam kelime sayıs1 }\end{array}$ \\
\hline Emoticon & Nümerik & $\begin{array}{l}\text { Mesajda geçen emoji sayıs1 / Mesajdaki } \\
\text { toplam kelime say1sı }\end{array}$ \\
\hline Number & Nümerik & $\begin{array}{l}\text { Mesajda geçen numara sayıs1 / Mesajdaki } \\
\text { toplam kelime sayıs1 }\end{array}$ \\
\hline Punctuation & Nümerik & $\begin{array}{l}\text { Mesaj içeriğindeki noktalama işareti sayısı } \\
\text { / Toplam token sayısı }\end{array}$ \\
\hline SpaceTab & Nümerik & $\begin{array}{l}\text { BoşlukTab sayısı / Mesajdaki toplam ke- } \\
\text { lime sayısı }\end{array}$ \\
\hline total & Nümerik & Toplam kelime sayıs1 \\
\hline $\begin{array}{l}\text { Unk- } \\
\text { nownWord }\end{array}$ & Nümerik & $\begin{array}{l}\text { Mesaj içeriğindeki Zemberek sözlüğünde } \\
\text { bulunmayan kelime miktarı / Mesajdaki } \\
\text { toplam kelime sayısı }\end{array}$ \\
\hline $\begin{array}{l}\text { WordWithA- } \\
\text { postrophe }\end{array}$ & Nümerik & $\begin{array}{l}\text { Kesme işareti içeren kelime sayısı / Mesaj- } \\
\text { daki toplam kelime sayıs1 }\end{array}$ \\
\hline TimeX & Nümerik & $\begin{array}{l}\text { Zaman ifadesi sayıs1 / Mesajdaki toplam } \\
\text { kelime sayıs1 }\end{array}$ \\
\hline Abbreviation & Nümerik & $\begin{array}{l}\text { Kisaltmaların sayıs1 / Mesajdaki toplam } \\
\text { kelime sayıs1 }\end{array}$ \\
\hline
\end{tabular}

$\mathrm{Bu}$ özellikler kullanılarak yapılan testlerin sonucu incelendiğinde \%78,57 ile en iyi başarımı Random Forest Algoritması yakalamıştır.

\section{2 adressType ve PartOfDay Özelliğinin Eklenmesi}

SMS verilerinin tekrar incelenmesi sonucu SMS gönderim zamanının mesajların doğru sınıfa yerleştirilebilmesi için 
etkili bir özellik olabileceği fark edilmiştir ve mesajları öğleden önce (am) ve öğleden sonra $(\mathrm{pm})$ bilgisini tutan PartOfDay adında yeni bir özellik eklenmiştir.

SMS'i gönderen adresler bir telefon numarası ya da bir şirket ismi olabilir. Örneğin kişisel bir mesajda gönderen bilgisini tutan Adress değişkenindeki değer "+09 555123 45 67" şeklinde bir telefon numarası iken; Bir devlet kurumunun Adress değişkeni değeri "PTT TAŞIMACILIK" şeklinde bir String olmaktadır. Ticari mesajların çoğunluğunda Adress değişkeni String içerdiği fark edilmiştir ve bunun bir özellik olarak kullanılmasına karar verilmiştir. SMS mesajı gönderen bilgisinden elde edilen adressType özelliği String ve number olarak mesajların gönderenlerini iki tipe ayırmaktadır.

\subsection{String2WordVector Filtresinin Kullanılması}

$\mathrm{Bu}$ başlığa kadar kullanılan özellikler SMS gövdesinden elde edilmiş oransal verilerden oluşmaktadır. Örneğin Tablo 5'deki kısa mesajda URL 1 kere kullanılmıştır, bu sayı tüm simgelere oranlandığında elde edilen değer 0,09 ( 1/(simge sayısı=11) ) olacaktır. URL özelliğinde olduğu gibi diğer oransal değerler de bu yolla elde edilmiştir.

Tablo 5. Önişleme adımı olarak simgeleme yöntemi örneği

\begin{tabular}{ll}
\hline \multicolumn{2}{l}{ SMS Gövdesi: } \\
$\begin{array}{l}\text { "Kampanya : } 30.01 .2018 \text { tarihine kadar B3SEW4 kodu ile indirimli alış- } \\
\text { veriş şans1 : http://www.abcd.com" }\end{array}$ \\
\hline Sonuç: & \\
\hline Simge & Tip \\
\hline Kampanya & Word \\
30.01 .2018 & Date \\
tarihine & Word \\
kadar & Word \\
B3SEW4 & WordWithApostrophe \\
kodu & Word \\
ile & Word \\
indirimli & Word \\
alışveriş & Word \\
şansl & Word \\
http://www.abcd.com & URL \\
\hline
\end{tabular}

Özellikler Zemberek kütüphanesi yardımı ile tokenize edilmekte ve tipleri toplam kelime sayısına oranlanarak (normalizasyon) yeni özellikleri Tablo 3'de ifade edildiği gibi çıkarılmaktadır. Literatürdeki metin sınıflandırma çalışmaları incelendiğinde, metinlerin sınıflandırılmasında StringtoWordVector gibi filtreler ile ön işlemlerden geçirilerek yeni özellikler çıkarılmaktadır.

$\mathrm{Bu}$ bölümde SMS gövdelerinden elde edilen yeni özellikler kullanılarak sınıflandırma sonuçlarının iyileştirilmesi amaçlanmaktadır. Zemberek kütüphanesi yardımı ile SMS gövdesi sirasıyla; tokenize edilir, kelime tipinde ise tokenize edilecek ve kullanılmak üzere kaydedilecek eğer kelime tipinde değilse özellik tipi kaydedilir. Örnek olarak verilen Tablo 3 yeni yaklaşımın girdi ve çıktılarını göstermektedir.

SMS gövdelerinin Tablo 3'de örneklendirilen şekilde ön işlemden geçirilmesi sonucu WEKA içerisindeki arff format11 dosyaya@attribute roots string satırı eklenmiştir. roots özelliği StringtoWordVector Filtresinden geçirilerek yeni özellik çıkarımları için kullanılır.

\section{4 letterCaseNormalization Özelliğin Eklenmesi}

Cümle içerisindeki küçük büyük harf oranı normalizasyonu yapılarak letterCaseNormalization özelliği oluşturulmuştur.

\subsection{Eklenen Özellikler ile Başarı Değişimlerinin İncelenmesi}

Her bir adımda eklenen yeni özellikler ve uygulanan yöntemler sınıflandırma modeli başarısına katkıda bulunmuştur. Verisetinin sınıf dağılımının dengesiz olması nedeni ile başarı değerlendirmesi yapılırken mikro ve makro doğruluk değerleri hesaplanmıştır. Şekil 7'de ve Şekil 8'de test edilen her bir algoritmanın yeni eklenen özelliklere bağlı olarak değişen makro ve mikro doğruluk oranlarına yer verilmiştir.

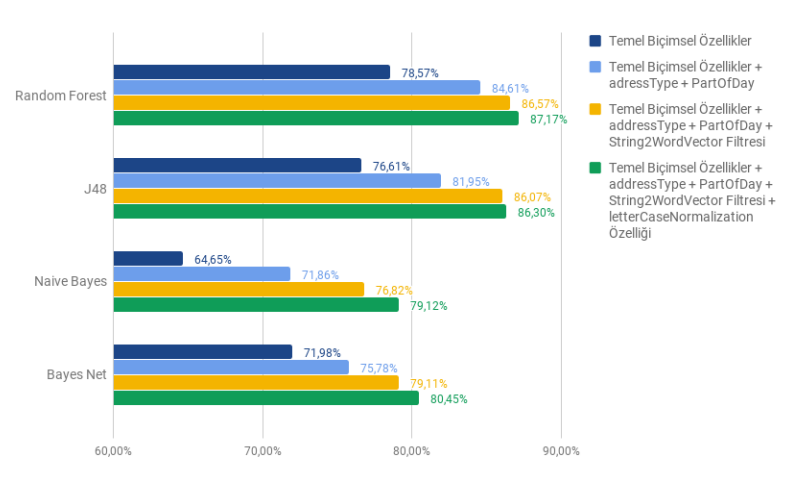

Şekil 7. Model Çıktılarının Mikro Doğruluk Bazında Eklenen Özelliklere Göre Karşılaştırılması

Random Forest algoritması ile oluşturulan model her adımda en başarılı sonuçları vermiştir. Mikro doğruluk bazında incelendiğinde, başlangıçta Random Forest ile doğru sınıflandırılan örnek oranı \%78,57 iken yapılan çalışmalar sonucu bu oran \%87,17'ye çıkarılmıştır. Benzer şekilde makro doğruluk bazında elde edilen çıktılar incelendiğinde Random Forest'ın tüm özellik testlerinde en yüksek sonuçları verdiği görülmüştür. 


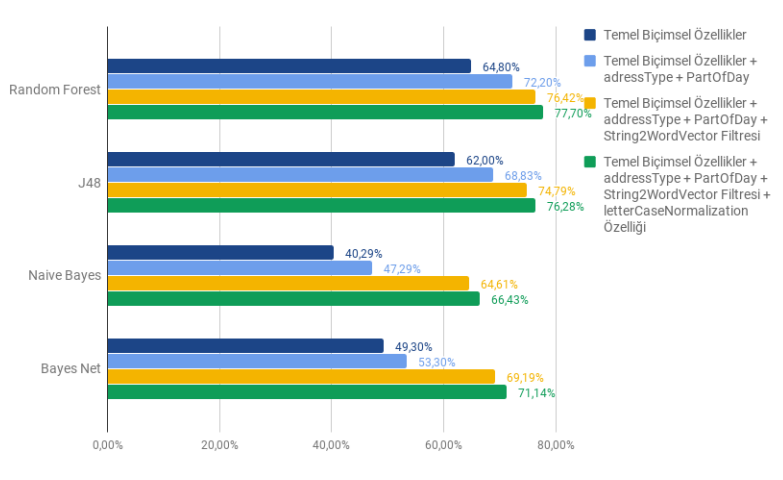

Şekil 8. Model Çıktılarının Makro Doğruluk Bazında Eklenen Özelliklere Göre Karşılaştırılması

\section{UYGULAMA METRÍKLERİ}

Sistem mimarisi sunduğu çok katmanlı mimari sayesinde mesajları daha hızlı bir şekilde kategorize etmeyi hedefler. Bu amaca yönelik yapılan çalışmaların sonucunda mesajların sınıflandırılmasında doğruluk ve hız artışı gözlemlenmiştir. Tablo 6'da "yalnızca sınıflandırma modeli kullanılması" ve "çok katmanlı süzgeçleme mimarisi kullanımı" durumlarında elde edilen zaman ve doğruluk oranı metriklerine yer verilmiştir.

Tablo 6. Karşılaştırmalı Uygulama Metrikleri

\begin{tabular}{lll}
\hline & $\begin{array}{l}\text { Yalnızca Sinıflan- } \\
\text { dırma Modeli Kul- } \\
\text { lanıldığında }\end{array}$ & $\begin{array}{l}\text { Çok Katmanlı } \\
\text { Süzgeçleme Mi- } \\
\text { marisi Kullanıldı- } \\
\text { ğında }\end{array}$ \\
\hline $\begin{array}{l}\text { Ortalama Mesaj Sınıflan- } \\
\text { dırma Süresi (ms) }\end{array}$ & $23 \mathrm{~ms}$ & $19 \mathrm{~ms}$ \\
$\begin{array}{l}\text { Doğru Sinıflandırma Oranı } \\
(\%)\end{array}$ & $\% 87,17$ & $\% 93,48$ \\
\hline
\end{tabular}

Tablo 6'da elde edilen sonuçlar göz önünde bulundurulduğunda "Çok Katmanlı Süzgeçleme Mimarisi”" kullanıldığında bir mesajın ortalama sınıflandırma süresi azalmış ve doğru sınıflandırılma oranı artmıştır.

Tablo 7'de sistemin genel başarımını ölçümleyen bir karmaşıklık matrisi gösterilmiştir. Karmaşıklık matrisi üzerindeki verilerin anlaşılabilirliğini arttırmak için kesinlik ve hassasiyet değerleri hesaplanmıştır. Kesinlik (precision) pozitif olarak tahmin edilen bir durumdaki başarıyı gösteren değerdir. Hassasiyet (recall) ise pozitif durumların ne kadar başarılı tahmin edildiğini gösteren değerdir.

Tablo 7 incelendiğinde karmaşıklık matrisinde bazı s1nıfların birbiri ile karıştırıldığı dikkat çekmektedir. Özellikle hatırlatıcı-ticari ve istenmeyen-ticari sınıfları arasında yüksek miktarda karışma olduğu gözlemlenmektedir. Bu karışıklığın sebebi ticari mesajların ve hatırlatıcı mesajlarının içeriklerinin anlamsal ve biçimsel yönlerden benzer olabilmesi ile açıklanabilir. Örneğin ticari içeriğe sahip bir mesaj gövdesi “Ayakkabllarda sezon indirimi! Son gün 28 Eylül!” olsun. Bu mesaj anlamsal olarak değerlendirildiğinde hem "hatırlatıcı" hem "ticari" mesaj niteliği taşımaktadır. Veri seti üzerinde örnektekine benzer mesajlar incelendiğinde bu karışıklığın sebebinin etiketleme işlemindeki etiketleyicinin tercihidir. Aynı şekilde "istenmeyen" ve "ticari” sınıflarında bir mesajın hangi sınıfa ait olduğu göreceli bir kavramdır. Antalya'da bir otelin reklamını içeren kısa mesaj yakın zamanda tatil planlayan birisi için "ticari” kısa mesaj niteliği taşırken, tatil planlamayan başka bir kimse için "istenmeyen" niteliği taşıyabilir. Bu karmaşıklıkların engellenebilmesi için sunulan öneri "Sonuç ve Gelecek Çalışmalar" başlığında açıklanmıştır.

Öte yandan, Zemberek'in kullanımının başarıya etkisi incelendiğinde yapılan testler sonucu sınıflandırma başarısının \%2 arttığı gözlenmiştir. Teorik olarak köklere ayrılan kelimelerin StringToWordVector filtresine etkisi köklerine ayrılmamış örneklere göre daha fazladır. Zemberek'ten elde edilen kelime kökleri ve özellikler kullanılmadığında oluşan doğruluk farkının az olmasının sebebi kullanılan veri setinin kelime bazında zengin olmamasından kaynaklanmaktadır. Daha geniş bir coğrafyadan, farklı yaş aralıkları ve düşüncelerden insanların kısa mesajları ile oluşturulmuş bir veri seti ile yapılacak testlerde sonuçlardaki farkın daha belirgin olması beklenmektedir.

Tablo 7. Karmaşıklık Matrisi

\begin{tabular}{|c|c|c|c|c|c|c|c|}
\hline $\begin{array}{l}\text { Gerçek Sınıf } \backslash \\
\text { Tahmin Edilen } \\
\text { Sınıf } \\
\end{array}$ & kişisel & ticari & $\begin{array}{l}\text { hatırla- } \\
\text { tıcı }\end{array}$ & $\begin{array}{l}\text { otp kod- } \\
\text { ları }\end{array}$ & $\begin{array}{l}\text { isten- } \\
\text { meyen }\end{array}$ & $\begin{array}{l}\text { Top- } \\
\text { lam }\end{array}$ & $\begin{array}{l}\text { Preci- } \\
\text { sion }\end{array}$ \\
\hline kişisel & 824 & 1 & 5 & 1 & 8 & 839 & $\% 98,21$ \\
\hline ticari & 0 & 226 & 15 & 3 & 1 & 245 & $\% 92,25$ \\
\hline hatırlatıcı & 7 & 36 & 464 & 2 & 1 & 510 & $\% 90,98$ \\
\hline otp kodları & 3 & 14 & 7 & 107 & 1 & 132 & $\% 81,06$ \\
\hline istenmeyen & 1 & 5 & 3 & 2 & 43 & 54 & $\% 79,63$ \\
\hline Recall & $\% 98,68$ & $\% 80,14$ & $\% 93,93$ & $\% 93,04$ & $\% 79,63$ & & \\
\hline
\end{tabular}

\section{SONUÇ VE GELECEK ÇALIŞMALAR}

Bu çalışmada Türkçe mesajlar için metin sınıflandırma yaklaşımlarından faydalanılarak mesajları beş farklı kategoriye ayıran mesaj asistanı uygulaması gerçeklenmiştir. Mesajları sınıflar halinde kategorize edebilmek için mesajların yapıları incelenip doğru sonuca götürecek özellikler belirlenmiştir. Adım adım özellikler belirlenirken her yeni eklenen özelliğin sınıflandırma sonucuna etkisi incelenmiştir. Sınıflandırma sonuçlarının yeni özelliklere göre değişimini incelerken Naive Bayes, Bayes Net, J48 ve Random Forest algoritmaları kullanılmıştır. Yapılan çalışmalar sonucunda Random Forest yöntemi \%87,17 ile doğruluk oranı ile en 
iyi sınıflandırma algoritması olmuş ve uygulamada bu algoritma kullanılmıştır. Ayrıca içerisinde 4 adet filtre bulunduran çok katmanlı süzgeçleme mimarisi sayesinde 5 farklı mesaj kategorisi \%93 oranında bir başarı ile daha kısa sürede gruplanabilmiştir. Ucuz ve etkili bir iletişim yöntemi olan SMS, pazarlama, kişisel, doğrulama vb. birçok amaçla kullanılan bir yöntemdir. Mesajların çeşitliliğinin artması ile mesajların okunabilirliği ve erişilebilirliği azalmaktadır. Geliştirilen uygulama ile kullanıcıların SMS gelen kutularını daha organize ve verimli kullanmasını sağlayarak, farklı mesajların yoğun bir şekilde bir arada bulunması yüzünden vakit ve enerji kaybının engellenmesi sağlanmıştır.

Öte yandan belirlenmiş sayıda sınıfı bulunan organize edilmiş bir kısa mesaj gelen kutusu kullanıcıların gereksinimlerini karşıllayabilir olmasına rağmen, gelecek çalışmalarda daha özelleşmiş bir gelen kutusu deneyimi için kullanıcıların kendilerine ait sınıfları oluşturabilmesi ve sistemin eğitilebilir olması bu sayede kullanıcı memnuniyetinin ve kullanım kolaylığının arttırılması hedeflenmektedir. Kullanıcının sınıf sayısını özelleştirmesi gibi kendi mesajları ile sistemi eğitebilmesi kişiselleştirilmiş bir sınıflandırma sistemini oluşturulmasına yönelik çalışmalar planlanmaktadır. Bu sayede veri setinin etiketlenmesi surasında etiketleyicinin göreceli yaklaşımı nedeniyle oluşabilecek hatalar kullanıcının sistemi kendi mesajları ile eğitmesi sonucu en aza indirgenebilecektir.

\section{BİLGí}

$\mathrm{Bu}$ proje TÜBİTAK tarafından organize edilen "2209-A Üniversite Öğrencileri Araştırma Projeleri Destekleme Programı" kapsamında desteklenmektedir.

\section{Kaynaklar}

[1] Zhu, S., Ji, X., Xu, W., \& Gong, Y. (2005, August). Multi-labelled classification using maximum entropy method. In Proceedings of the 28th annual international ACM SIGIR conference on Research and development in information retrieval (pp. 274-281). ACM.

[2] Klimt, B., \& Yang, Y. (2004, September). The enron corpus: A new dataset for email classification research. In European Conference on Machine Learning (pp. 217-226). Springer, Berlin, Heidelberg.

[3] Healy, M., Delany, S. J., \& Zamolotskikh, A. (2004). An assessment of case base reasoning for short text message classification In Proceedings of the 15th. Irish Conference on Artificial Intelligence and Cognitive Sciences (AICS'04), pp.9-18, 2004.

[4] Najadat H., Abdulla, N., Abooraig, R. ve Nawasrah S. (2014). Mobile SMS Spam Filtering based on Mixing Classifiers. International Journal of Advanced Computing Research,1.
[5] Joe, I., \& Shim, H. (2010, December). An SMS spam filtering system using support vector machine. In International Conference on Future Generation Information Technology (pp. 577-584). Springer, Berlin, Heidelberg.

[6] Mahmoud, T. M., \& Mahfouz, A. M. (2012). SMS spam filtering technique based on artificial immune system. International Journal of Computer Science Issues (IJCSI), 9(2), 589.

[7] Patel, F. N., \& Soni, N. R. (2012). Text mining: A Brief survey. International Journal of Advanced Computer Research, 2(4), 243-248.

[8] Al-Talib, G. A., \& Hassan, H. S. (2013). A study on analysis of SMS classification using TF-IDF Weighting. International Journal of Computer Networks and Communications Security, 1(5), 189-194.

[9] Parimala, R., \& Nallaswamy, R. (2012). A Study on Analysis of SMS Classification Using Document Frequency Thresold. International Journal of Information Engineering and Electronic Business, 4(1), 44.

[10] Deng, W. W., \& Peng, H. (2006, August). Research on a naive bayesian based short message filtering system. In Machine learning and cybernetics, 2006 international conference on (pp. 1233-1237). IEEE.

[11] Kawade, D. R., \& Oza, K. S. (2015). SMS spam classification using WEKA. International Journal of Electronics Coтmunication and Computer Technology, 5, 43-7.

[12] Mathew, K., \& Issac, B. (2011, December). Intelligent spam classification for mobile text message. In Computer Science and Network Technology (ICCSNT), 2011 International Conference on (Vol. 1, pp. 101-105). IEEE.

[13] Uysal, A. K., Günal, S., Ergin, S., \& Günal, E. Ş. (2012, April). Detection of SMS spam messages on mobile phones. In Signal Processing and Communications Applications Conference (SIU), 2012 20th (pp. 1-4). IEEE.

[14] Kilic, E., Arslan, S. N., \& Guvensan, M. A. (2014, April). 3-Tier hybrid approach for SMS filtering. In Signal Processing and Communications Applications Conference (SIU), 2014 22nd (pp. 1950-1953). IEEE.

[15] StringToWordVector. (2016, April 14). Retrieved July/August, 2018, from http://weka.sourceforge.net/doc.stable/weka/filters/unsupervised/attribute/StringToWordVector.html

[16] Naive Bayes Slide. (2017). Retrieved July 23, 2018, from https://web.stanford.edu/class/cs124/lec/naivebayes.pdf

[17] Cooper, G. F., \& Herskovits, E. (1992). A Bayesian method for the induction of probabilistic networks from data. Machine learning, 9(4), 309-347.

[18] J48. (2018, September 04). Retrieved July 23, 2018, from http:// weka.sourceforge.net/doc.dev/weka/classifiers/trees/J48.html

[19] Kaur, G., \& Chhabra, A. (2014). Improved J48 classification algorithm for the prediction of diabetes. International Journal of Computer Applications, 98(22).

[20] Liaw, A., \& Wiener, M. (2002). Classification and regression by randomForest. $R$ news, 2(3), 18-22. 